\title{
STUDIES ON SIDA ACUTA HYDROGEL I: PROCESSING AND PHYSICOCHEMICAL PROPERTIES OF THE DERIVED HYDROGEL OBTAINED FROM SOUTH EAST NIGERIA
}

\author{
OKAFO SINODUKOO EZIUZ0 ${ }^{*}{ }^{*}$, CHUKWU AMARAUCHE ${ }^{2}$ \\ ${ }^{1}$ Department of Pharmaceutics and Industrial Pharmacy, Faculty of Pharmacy, Delta State University, Abraka, Nigeria, ${ }^{2}$ Department of \\ Pharmaceutical Technology and Industrial Pharmacy, Faculty of Pharmaceutical Sciences, University of Nigeria, Nsukka, Nigeria \\ Email: sinokaf@yahoo.com
}

Received: 20 Nov 2015 Revised and Accepted: 20 Apr 2017

\section{ABSTRACT}

Objective: Sida acuta is a plant that is widely distributed in the subtropical regions where it is found in bushes, in farms and around habitations. This study was carried out to isolate hydrogel from this freely available natural source.

Methods: The sieved dried powder from the leaves of Sida acuta was macerated in distilled water. The mucilage formed was filtered and precipitated with equal volumes of isopropyl alcohol. This was repeated using ethanol and acetone respectively. The precipitated hydrogel was purified by washing twice with isopropyl alcohol, once with acetone and dried in the oven at $40{ }^{\circ} \mathrm{C}$ for $8 \mathrm{~h}$.

Results: The mean percentage yield of the hydrogel as obtained was $10.15 \pm 1.22,9.24 \pm 0.74$ and $7.90 \pm 0.03 \% \mathrm{w} / \mathrm{w}$ for isopropyl alcohol, ethanol and acetone precipitated hydrogels respectively. The swelling index of the hydrogel in water was $10.00 \pm 0.02$. The solubility of the hydrogel in water at $28{ }^{\circ} \mathrm{C}$ and $80^{\circ} \mathrm{C}$ were $7.00 \pm 0.41$ and $8.63 \pm 0.63$ respectively. The solubility of the hydrogel in $0.1 \mathrm{~N} \mathrm{NaOH}$ and $0.1 \mathrm{~N} \mathrm{HCl} \mathrm{solutions}$ were $11.86 \pm 1.75$ and $5.67 \pm 0.58 \mathrm{mg} / \mathrm{ml}$ respectively. The loss on drying was $145 \pm 1.87 \%$ while total ash was $53.33 \pm 5.77 \mathrm{mg}$ per $1 \mathrm{~g}$ hydrogel. The viscosity of a $1 \% \mathrm{w} / \mathrm{v}$ solution of the hydrogel using rotor 1 of a Brookfield viscometer at $30 \mathrm{rpm}$ was $71.4 \pm 0.00 \mathrm{mPas}$. The $\mathrm{pH}$ of a $1 \% \mathrm{w} / \mathrm{v}$ solution was $6.60 \pm 009$. The Carr's index and Hausner ratio were $38.77 \pm 1.69 \%$ and $1.63 \pm 0.05$ respectively.

Conclusion: The hydrogel obtained from powdered dried leaves of Sida acuta may have potential in various drug delivery systems.

Keywords: Sida acuta hydrogel, Processing, Physicochemical properties, South East Nigeria.

(c) 2017 The Authors. Published by Innovare Academic Sciences Pvt Ltd. This is an open access article under the CC BY license (http://creativecommons.org/licenses/by/4.0/) DOI: http://dx.doi.org/10.22159/ijpps.2017v9i6.10097

\section{INTRODUCTION}

The quest for safer and more affordable pharmaceutical raw materials has made pharmaceutical scientists intensify research efforts towards developing raw materials of natural origin.

Natural gums and mucilages are preferred to the synthetic ones because they are biocompatible, cheap, and readily available. Also, the natural excipients are preferred to the synthetic and semisynthetic ones because of their apparent lack of toxicity, low cost, opening up jobs especially in developing countries and preserving foreign exchange [1-4]. Demand for these substances is increasing and new sources are being developed.

Gums and mucilages are typically heterogeneous polyuronides with a similar composition which upon hydrolysis yield sugars such as arabinose, galactose, glucose, mannose, xylose and various uronic acids [5]. Mucilages function as storage material, water storage reservoir and protection for germinating seeds. Mucilages are often found in epidermal leaf cells (Senna), seed coats (linseeds, psyllium), roots (marshmallow) and barks (Slippery elm) [6]. Gums are considered to be pathological products while mucilage is formed by normal metabolism. The gums are amorphous translucent substances which are insoluble in alcohol and most organic solvents. They are soluble in water and give a viscous, sticky solution while some form a jelly-like mass.

Gums are abnormal products, formed by injury on the plant, unfavorable conditions (e. g. drought) and by a breakdown of cell walls [7].

Gums and mucilages have diverse pharmaceutical applications such as a diluent, binder, a disintegrant in tablets, thickeners in oral liquids, protective colloids in suspensions, gelling agents in gels, and bases in suppository [8]. They are also used in cosmetics, paints, textiles, and paper making [9].

Some indigenous gums, such as grewia gum and mucuna gum have been studied locally in Nigeria as pharmaceutical excipients. Grewia polysaccharide gum is obtained by extraction from the inner stem bark of the edible plant Grewia mollis, Linn, (Fam. Tiliaceae). The gum has been isolated and some of its physicochemical properties have been evaluated [10]. The polysaccharide gum consists of glucose and rhamnose as the main monosaccharide components and galacturonic acid as the main sugar acid [10]. Grewia polysaccharide gum has found wide application in pharmaceutical formulations such as polymer matrices in sustained release solid dosage forms [11], binders in tablets [12] stabilizers or suspending agents in liquid dosage forms and in bioadhesive drug delivery systems [13]. Mucuna gum is a good suspending agent, a stabilizing agent in dosage formulations such as suspensions and emulsions [14], a good binder in tablets [15] and a good candidate for sustained drug delivery via microencapsulation [16].

The stability of the emulsion prepared with mucuna gum was compared with that of emulsions prepared with acacia or tragacanth and suspensions of sulphadimidine or zinc oxide prepared with tragacanth gum were compared with those prepared with mucuna gum. The result indicated that mucuna gum can be usefully employed as both an emulsifying and a suspending agent [14].

Sida acuta is a shrub belonging to Malvaceae family. The plant is widely distributed in the subtropical regions where it is found in bushes, in farms, and around habitations. Sida acuta is a plant of wide usage in traditional medicine. The picture of Sida acuta leaves is shown on fig. 1. Following these traditional usages, many studies have been conducted in laboratories for the efficiency of the plant. It is now evident that the plant has a good antiplasmodial activity due to its alkaloids, principally cryptolepine the main alkaloid of the plant. It is also demonstrated that the plant is active on several bacterial strains. Many other compounds which are demonstrated to have interesting pharmacological properties alone have been isolated from the plant, in addition, the plant may have many other properties since it has not been tested for all desired pharmacological activities [17]. 
Preliminary phytochemical screening of leaf extracts of Sida acuta. L shows that the chloroformic extract contains carbohydrates, alkaloids, saponins, fixed oil but no phytosterols while the ethanolic extract contains carbohydrates, alkaloids, saponins, fixed oil and phytosterols [18]. Sida acuta contained tannins, saponins, flavonoids and sterols chemical compounds [19].

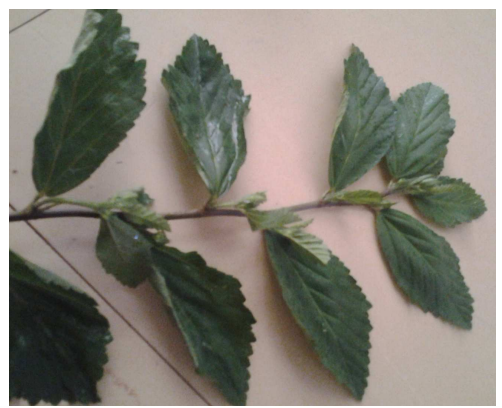

Fig. 1: Sida acuta leaves

Searches through literature showed no citations on the isolation and uses of hydrogel obtained from Sida acuta in drug delivery and that stimulated the interest in this particular research work.

\section{MATERIALS AND METHODS}

\section{Materials}

Isopropyl alcohol, acetone (Guangxing Guanghua Chemical, China), absolute ethanol, chloroform (May and Baker, Dagenham England), Methanol (BDH, Poole, England) and other chemicals used were of analytical grades.

The leaves were collected from Sida acuta plants from bushes in the New G. R. A area of Trans-Ekulu, Enugu, Enugu state, Nigeria.

\section{Isolation and purification of hydrogel}

The leaves from Sida acuta plant were dried, powdered, and passed through a sieve of aperture size $600 \mu \mathrm{m}$. A $200 \mathrm{~g}$ of the sieved dried leaves powder was mixed with $1500 \mathrm{ml}$ of distilled water and allowed to macerate for $6 \mathrm{~h}$. The mixture was boiled for $1 \mathrm{~h}$ at $100^{\circ} \mathrm{C}$ to ensure complete break-up of cells to release the mucilage and kept aside for settling. After $2 \mathrm{~h}$, the mixture was filtered, and to the filtrate $(900 \mathrm{ml})$, equal volumes of isopropyl alcohol were added and kept in a refrigerator at $8-10^{\circ} \mathrm{C}$ for $6 \mathrm{~h}$. To the marc left, $1000 \mathrm{ml}$ of distilled water was added and kept for about $1 \mathrm{~h}$ to wash out the remaining mucilage. The mucilage $(1200 \mathrm{ml})$ was separated from the marc using a muslin cloth and precipitated with equal volumes of isopropyl alcohol [3]. The hydrogel was purified by using isopropyl alcohol and acetone as reported by previous researchers [20]. The hydrogel was soaked into two volumes excess of isopropyl alcohol. The hydrogel-solvent slurry was allowed to stand for $30 \mathrm{~min}$. The precipitate was collected by filtration using a muslin cloth. washed twice with isopropyl alcohol and once with acetone [21]. Finally, it was dried in the oven at $40{ }^{\circ} \mathrm{C}$ for $8 \mathrm{~h}$. The hydrogel was stored separately in a clean, dry, and closed container. This process was carried out in triplicate. The process was also repeated using absolute ethanol or acetone as the precipitating agent. The percentage yield for the hydrogels produced using the isopropyl alcohol, absolute ethanol and acetone respectively were recorded.

\section{Phytochemical analysis}

The tests for identification of glycosides, sterols, flavonoids, saponins, tannins, phenols, terpenes and alkaloids were carried out on the powdered dried Sida acuta leaves and the precipitated hydrogel using the methods used by [22].

\section{Physicochemical properties}

Organoleptic properties such as colour, taste, odour, shape and texture were determined for the Sida acuta hydrogel. Other physicochemical properties were determined. They include $\mathrm{pH}$ of $1 \%$ solution, swelling index, solubility, loss on drying, acute toxicity, the angle of repose, bulk and true densities, Hausner ratio, Compressibility index, ash values, microbial count and viscosity.

\section{pH}

A $1 \% \mathrm{w} / \mathrm{v}$ solution of the Sida acuta hydrogel was prepared by dissolving $1 \mathrm{~g}$ of Sida acuta hydrogel in $100 \mathrm{ml}$ of distilled water. Distilled water was used to calibrate a model HI $2211 \mathrm{pH} / \mathrm{ORP}$ meter (Hanna Instruments) after which it was used to determine the $\mathrm{pH}$ of the Sida acuta hydrogel. This was repeated four times. The $\mathrm{pH}$ for $1 \% \mathrm{w} / \mathrm{v}$ acacia solution was also determined.

\section{Bulk and tapped densities}

The Sida acuta hydrogel was sieved through a $300 \mu \mathrm{m}$ sieve. A $10 \mathrm{~g}$ Sida acuta hydrogel was weighed and poured into a $50 \mathrm{ml}$ graduated cylinder and bulk volume recorded. The cylinder was tapped 100 times and the tapped volume recorded. The bulk and tapped densities were calculated. This was done three times.

\section{Carr's compressibility index}

This was calculated from the bulk and tapped densities as follows:

$$
\text { Corr's Index }=\begin{gathered}
\text { Tapped density Bulk density } \\
\text { Tappod donsity }
\end{gathered}
$$

\section{Hausner ratio}

This was also calculated from the bulk and tapped densities as follows:

$$
\text { Hustuer Fuliv }=\frac{\text { Tupped densily }}{\text { Bulkdensity }}
$$

\section{Angle of repose}

This was determined by the Platform method. A hollow cylinder that was opened at both end, with a diameter of $5.5 \mathrm{~cm}$ was placed on top of a cream jar with diameter $5.5 \mathrm{~cm}$ on a table. A $20 \mathrm{~g}$ Sida acuta hydrogel was poured into the cylinder on top of the cream jar. The hollow cylinder was removed by pulling it up from the cream jar. The Sida acuta hydrogel formed a cone on top of the cream jar. The height and diameter of the cone were recorded. The drained angle of repose, $\theta$ was determined. This was done in triplicate.

$$
\theta=\operatorname{Tan}^{-1} \frac{h}{r}
$$

Where $\mathrm{h}=$ height of cone and $\mathrm{r}=$ radius of the cone.

\section{Swelling index}

The swelling index of the Sida acuta hydrogel was determined according to British Pharmacopoeia method 6 [23]. A $1 \mathrm{~g}$ of the Sida acuta hydrogel was transferred into a $50 \mathrm{ml}$ ground glass stoppered measuring cylinder graduated over a height of 120 to $130 \mathrm{~mm}$ in 0.5 divisions. $25 \mathrm{ml}$ of distilled water was added and shaken vigorously every $10 \mathrm{~min}$ for $1 \mathrm{~h}$. It was kept for $24 \mathrm{~h}$ after which the volume of the swollen hydrogel was recorded. The swelling index is the volume in ml taken up by the swelling of $1 \mathrm{~g}$ of plant material under specified conditions. This was carried out in triplicate.

Swelling index was also determined using the method used by Sameer [24]. $1 \mathrm{~g}$ of Sida acuta hydrogel was weighed and transferred into a pre-weighed $15 \mathrm{ml}$ centrifuge tube. $10 \mathrm{ml}$ of distilled water was added to it and it was shaken thoroughly. This was centrifuged at $3500 \mathrm{rpm}$ for $45 \mathrm{~min}$. The centrifuge tube with the swollen hydrogel in it was weighed. This was done in triplicate and also for acacia hydrogel. The swelling index was calculated from the formula:

$$
\text { Swelling Index }=\frac{W f-W i}{W t} X 100 \%
$$

Where $\mathrm{Wf}=$ final weight, and $\mathrm{Wi}=$ initial weight

\section{Effect of pH on the hydrogel swelling}

The hydrogel was tested for its swelling characteristics at acidic and basic $\mathrm{pH}$ using $0.1 \mathrm{~N} \mathrm{HCl}$, and $0.1 \mathrm{~N} \mathrm{NaOH}$ solution respectively, 


\section{Viscosity}

The viscosities of different concentrations $(1,2,3,4$, and $5 \% \mathrm{w} / \mathrm{v})$ of the Sida acuta hydrogel were tested at different rotor speeds $(6,12,30$ and $60 \mathrm{rpm}$ ) using rotor 3 of a Brookfield Viscometer (NDJ-5S Viscometer, England Lab science). The viscosity of a $1 \% \mathrm{w} / \mathrm{v}$ Sida acuta hydrogel solution was determined at different temperatures $\left(28,40,60\right.$ and $\left.80^{\circ} \mathrm{C}\right)$

\section{Solubility}

The solubility of the hydrogel in water, ethanol, chloroform and acetone was determined. The solubility in water was determined according to the method described by Dakia et al. [25], with minor modifications. One g of the Sida acuta hydrogel was added to $100 \mathrm{ml}$ distilled water and the mixture was stirred for $30 \mathrm{~min}$. The solubility was measured by stirring the mixture at different temperatures, room temperature $\left(28 \pm 2{ }^{\circ} \mathrm{C}\right)$ and elevated temperature $\left(80^{\circ} \mathrm{C}\right)$ in order to determine the effect of temperature on the solubility of the hydrogel. The hydrogel solution was then centrifuged at 3,500 g for $45 \mathrm{~min}$ to remove the insoluble material, and known volume $(20 \mathrm{ml})$ of the supernatant was transferred into a crucible and oven dried at $105{ }^{\circ} \mathrm{C}$ for $24 \mathrm{~h}$ until constant weight [26]. The solubility was calculated by the weight difference and expressed in dry basis per volume of supernatant used. The solubility measurement was carried out in triplicate and the average of three individual measurements was considered for further data analysis.

\section{Determination of ash value [27]}

\section{Total ash}

A 2 g Sida acuta hydrogel was accurately weighed, in a previously ignited and tared crucible. It was spread in an even layer and ignited by gradually increasing the heat to $500-600{ }^{\circ} \mathrm{C}$ until it was white, indicating the absence of carbon. It was cooled in a desiccator and weighed. The total ash content was calculated in mg per g of Sida acuta hydrogel sample. This was carried out in triplicate.

\section{Acid-insoluble ash}

To the crucible containing the total ash, $25 \mathrm{ml}$ of hydrochloric acid $(\sim 70 \mathrm{~g} / \mathrm{l})$ TS was added, covered with a watch-glass and boiled gently for $5 \mathrm{~min}$. The watch-glass was rinsed with $5 \mathrm{ml}$ of hot water and added to the crucible. The insoluble matter was collected on an ashless filter paper and washed with hot water until the filtrate was neutral. The filter paper containing the insoluble matter was transferred to the original crucible, dried on a hot-plate and ignited to constant weight. The residue was allowed to cool in a suitable desiccator for $30 \mathrm{~min}$, then weighed without delay. The acidinsoluble ash content in mg per g of Sida acuta hydrogel sample was calculated. This was carried out in triplicate.

\section{Water-soluble ash}

$25 \mathrm{ml}$ of water was added to the crucible containing the total ash and boiled for $5 \mathrm{~min}$. The insoluble matter was collected in an ashless filter paper. It was washed with hot water and ignited in a crucible for $15 \mathrm{~min}$ at a temperature not exceeding $450{ }^{\circ} \mathrm{C}$. The weight of this residue in mg was subtracted from the weight of total ash. The content of water-soluble ash in mg per g hydrogel powder sample was calculated. This was carried out in triplicate.

\section{Loss on drying}

A 2 g Sida acuta hydrogel was weighed, put in a pre-weighed crucible and dried at $105^{\circ} \mathrm{C}$ for $2 \mathrm{~h}$ in an oven. After $2 \mathrm{~h}$, the new weight was recorded, and percentage weight loss on drying was calculated. Weight loss on drying was determined by formula,

$$
\text { Weight lass on drying = Initial weight of sample }- \text { final weight of sample }
$$

Percentage loss of moisture on drying was calculated using the formula.

$$
L O D(\%)=\frac{\text { Weight of water in sample }}{\text { weight of dry sample }} X 100
$$

------------6

The weight loss on drying indicates the amount of moisture present in the material available to interact with other material.

\section{Determination of browning and charring temperatures}

The browning and charring temperatures of Sida acuta hydrogel were determined using a melting point apparatus (DBK Instruments, India).

\section{Microbial count [27]}

The microbial count of the Sida acuta hydrogel was performed for the total aerobic microbial count of bacteria and fungi using the plate count method. The limit of colony forming units (cfu) for bacteria was 300 and for fungi was 100 .

\section{Plate count}

A $0.1 \mathrm{~g}$ of Sida acuta hydrogel was dissolved in sterilized water, and the volume was adjusted to $10 \mathrm{ml}$ with the same medium. A Serial dilution was made by transferring $1 \mathrm{ml}$ of hydrogel solution into a test tube and making it up to $10 \mathrm{ml}$ with sterilized water. Further dilutions were made to obtain $10^{-4}$ and $10^{-5}$ hydrogel solutions. These processes were repeated using acacia gum.

For bacteria, nutrient agar was prepared at about $45^{\circ} \mathrm{C}$ and poured into twelve Petri dishes of $10 \mathrm{~cm}$ diameter respectively and they were allowed to solidify. A $0.1 \mathrm{ml}$ of the $10^{-4}$ Sida acuta hydrogel solution was transferred into three of the Petri dishes respectively. This was repeated using 10-5 Sida acuta hydrogel, 10-4 acacia gum, and $10^{-5}$ acacia gum solutions respectively. They were spread on the surface of the solidified medium in a Petri dish using a glass spreader. The hydrogel solutions were allowed to drain into the agar. The Petri dishes were inverted and incubated at $35^{\circ} \mathrm{C}$ for $1 \mathrm{~d}$. The number of colonies formed was counted and the results calculated using the average count for the respective three plates, up to a maximum of 300 .
For fungi, Sabouraud glucose agar was prepared at about $45^{\circ} \mathrm{C}$ and poured into twelve Petri dishes of $10 \mathrm{~cm}$ in diameter respectively and they were allowed to solidify. A $0.1 \mathrm{ml}$ of the $10^{-4}$ hydrogel solution was transferred into three of the Petri dishes respectively. This was repeated using10-5 Sida acuta hydrogel, 10-4 acacia gum, and $10^{-5}$ acacia gum solutions respectively. They were spread on the surface of the solidified medium in a petri dish using a glass spreader. The hydrogel solutions were allowed to drain into the agar. The Petri dishes were inverted and incubated at $28^{\circ} \mathrm{C}$ for $3 \mathrm{~d}$.

The number of colonies formed was counted and the results calculated using the dish with not more than 100 colonies.

\section{Acute toxicity studies}

The method specified by [28] was used with little modification. Ten male Winstar rats were procured from the animal house of Delta State University, Abraka. The animals were housed in cages and maintained under standard conditions at $28 \pm 2{ }^{\circ} \mathrm{C}$ and relative humidity $60-65 \%$ and $12 \mathrm{~h}$ light and $12 \mathrm{~h}$ dark cycles each day for fourteen days. All animals were fed with the standard rodent pellet diet, and water ad-libitum. Permission was sought and received from the ethical committee on animal studies of Delta State University, Abraka. The animals were grouped into two, with each group having five rats. The rats were made to fast overnight and weighed the next day. An oral dose of $300 \mathrm{mg} / \mathrm{kg}$ body weight of Sida acuta hydrogel was administered to rats in group A while an oral dose of $2000 \mathrm{mg} / \mathrm{kg}$ body weight was administered to rats in group B. The rats were observed for $2 \mathrm{~h}$ for any sign of toxicity. They were further observed daily for $14 \mathrm{~d}$ for the sign of toxicity.

\section{RESULTS AND DISCUSSION}

\section{Isolation and purification of hydrogel}

The mean percentage yield $( \pm S D)$ was $10.15 \pm 1.22,9.24 \pm 0.74$, and $7.90 \pm 0.03 \%$ for Sida acuta hydrogel extracted with isopropyl alcohol, absolute ethanol, and acetone respectively.

\section{Organoleptic properties}

This is shown on table 1 below. 
Table 1: Organoleptic properties of Sida acuta hydrogel

\begin{tabular}{|c|c|c|c|c|}
\hline Appearance & Colour & Odour & Taste & Texture \\
\hline Powder & Light brown & Slight odour & Tasteless & Slightly rough \\
\hline
\end{tabular}

Table 2: Phytochemical tests of Sida acuta hydrogel

\begin{tabular}{llll}
\hline S. No. & Test & Dried powder from sida acuta leaves & Sida acuta hydrogel \\
\hline 1 & Tannin & + \\
2 & Alkaloid & + \\
3 & Saponin & + \\
4 & Terpenoids & + \\
5 & Steroid & + \\
6 & Flavonoid & + \\
7 & Glycosides & + & - \\
8 & Mucilage (Ruthenium red test) & + \\
\hline
\end{tabular}

Key: += Present,-= Absent

\section{Phytochemical analysis}

This is shown on table 2 .

\section{Physicochemical properties}

\section{pH}

The $\mathrm{pH}$ of a $1 \% \mathrm{w} / \mathrm{v}$ solution of the hydrogel at $28 \pm 2{ }^{\circ} \mathrm{C}$ was determined using a pH meter (HI $2211 \mathrm{pH} / \mathrm{ORP}$ meter, Hanna Instruments). The mean $\mathrm{pH}(. \pm \mathrm{SD})$ of $1 \% \mathrm{w} / \mathrm{v}$ solution of Sida acuta hydrogel and acacia gum was $6.60 \pm 0.09$ and $3.93 \pm 0.01$ respectively This showed that both hydrogels were acidic, though acacia was more acidic. $\mathrm{pH}$ is one of the factors that affect the solubility of a solid in a liquid. The $\mathrm{pH}$ of the Sida acuta hydrogel suggested that it may be more soluble in a basic (e. g. simulated intestinal fluid, SIF) than acidic (simulated gastric fluid, SGF) medium.

\section{Bulk and tapped densities}

The mean bulk and tapped densities $( \pm \mathrm{SD})$ were $0.24 \pm 0.01 \mathrm{~g} / \mathrm{ml}$ and $0.39 \pm 0.10 \mathrm{~g} / \mathrm{ml}$ respectively.

\section{Carr's compressibility index}

The mean compressibility index value $( \pm$ SD) of $38.77 \pm 1.69 \%$ indicated that the Sida acuta hydrogel had a very poor flow property. This showed that the cohesive forces between the particles were very high and this suggested that it could be used as a dry binder.

\section{Hausner ratio}

Mean value $( \pm S D)$ of $1.63 \pm 0.05$ indicated that Sida acuta hydrogel powder was cohesive and less free flowing. This showed that the interparticle friction was high.

\section{The angle of repose}

The mean drained angle of repose value $( \pm S D)$ of $46.47 \pm 0.000$ indicated a very poor flow. The hydrogel could not flow through the funnel which necessitated the use of platform method instead of funnel method. This may be due to the very small particle size of the hydrogel $(<300 \mu \mathrm{m})$ which may favour the dominance of cohesive forces over repulsive forces.

Table 3: Micromeritic properties of Sida acuta hydrogel

\begin{tabular}{ll}
\hline Property & Value \\
\hline Angle of repose & $46.47 \pm 0.00^{\circ}$ \\
Bulk density & $0.24 \pm 0.01 \mathrm{~g} / \mathrm{ml}$ \\
Tapped density & $0.39 \pm 0.10 \mathrm{~g} / \mathrm{ml}$ \\
Compressibility index & $38.77 \pm 1.69 \%$ \\
Hausner ratio & $1.63 \pm 0.05$ \\
\hline
\end{tabular}

The number of experiments, $n=3$, The data were given in mean \pm SD

\section{Swelling index}

The swelling index of $1 \mathrm{~g}$ of Sida acuta hydrogel in $25 \mathrm{ml}$ of water was $10 \pm 0.2 \mathrm{ml}$. The swollen hydrogel occupied a mean volume $(. \pm \mathrm{SD})$ of $10 \pm 0.2 \mathrm{ml}$ while the remaining $15 \mathrm{ml}$ (supernatant), containing the dissolved hydrogel which was viscous but mobile. The swelling index determined using the method of sameer et al. [24] was $984 \pm 31 \%$. This showed that the Sida acuta hydrogel could be used as a swellable hydrophilic matrix in the formulation of sustained release preparations. The $1 \mathrm{~g}$ acacia gum did not swell but dissolved in water in both methods to form a slightly viscous acacia mucilage.

\section{Effect of $\mathrm{pH}$ on mucilage swelling}

The swelling index of $1 \mathrm{~g}$ of the Sida acuta hydrogel was $8 \pm 0.01 \mathrm{ml}$ and $25 \pm 0.02 \mathrm{ml}$, in $25 \mathrm{ml}$ of $0.1 \mathrm{~N} \mathrm{HCl}$ and $0.1 \mathrm{~N} \mathrm{NaOH}$ respectively. In the dilute acid medium, the hydrogel became swollen $(8 \mathrm{ml})$ and floated on top, while it dissolved and formed a thick viscous mucilage in dilute alkaline solution. The acacia gum did not swell but dissolved completely to form acacia mucilage in the $0.1 \mathrm{~N} \mathrm{HCl}$ and $0.1 \mathrm{~N} \mathrm{NaOH}$ solutions respectively.

\section{Viscosity}

As the concentration of the Sida acuta hydrogel solution increased from 1 to $5 \% \mathrm{w} / \mathrm{v}$ as shown on table 4 and fig. 2 below, using rotor (spindle) 3 of a Brookfield viscometer, at a speed of $6 \mathrm{rpm}$, the viscosity increased from 0 to $12,520 \pm 0 \mathrm{mPas}$, at room temperature $\left(28 \pm 2{ }^{\circ} \mathrm{C}\right)$. Table 4 and fig. 3 also show that for a given concentration of the hydrogel solution (e. g. $5 \% \mathrm{w} / \mathrm{v}$ ), the viscosity decreased $(12,520 \pm 0$ to $1960 \pm 0 \mathrm{mPas})$ as the speed of rotation of the rotor or shear rate increased ( 6 to $60 \mathrm{rpm}$ ). Table 5 shows the effect of temperature on the viscosity of Sida acuta hydrogel. The viscosity of a $1 \% \mathrm{w} / \mathrm{v}$ solution of Sida acuta hydrogel at room temperature $(28 \pm 2$ ${ }^{\circ} \mathrm{C}$ ) using spindle (rotor) 1 at $30 \mathrm{rpm}$ is $71.4 \pm 0.00 \mathrm{mPas}$. This is comparable to grewia gum which has a viscosity of $2.685 \mathrm{mPas}$ at $0.5 \% \mathrm{w} / \mathrm{v}$ concentration and is used as a binder and as a suspending agent [10]. The viscosity of Sida acuta hydrogel decreases ( $71.4 \pm 0.00$ to $25.2 \pm 0.00 \mathrm{mPas}$ ) as the temperature increases, (28 to $80^{\circ} \mathrm{C}$ ), as shown in fig. 4 . The rheological properties suggest that the hydrogel may be used as a binder in solid dosage forms and as viscosity enhancer or suspending agent in liquid dosage forms. 
Table 4: The viscosity of different concentrations of Sida acuta hydrogel using rotor 3 at room temperature $\left(30^{\circ} \mathrm{C}\right)$ and at different speeds (rpm)

\begin{tabular}{|c|c|c|c|c|c|}
\hline \multirow[t]{2}{*}{ Speed } & \multicolumn{5}{|c|}{ Concentration of sida acuta hydrogel } \\
\hline & $1 \% \mathrm{w} / \mathrm{v}$ & $2 \% \mathrm{w} / \mathrm{v}$ & $3 \% \mathrm{w} / \mathrm{v}$ & $4 \% \mathrm{w} / \mathrm{v}$ & $5 \% \mathrm{w} / \mathrm{v}$ \\
\hline $6 \mathrm{rpm}$ & - & $120 \pm 0 \mathrm{mPas}$ & $920 \pm 0 \mathrm{mPas}$ & $4620 \pm 0 \mathrm{mPas}$ & $12520 \pm 0 \mathrm{mPas}$ \\
\hline $12 \mathrm{rpm}$ & - & $120 \pm 0 \mathrm{mPas}$ & $740 \pm 0 \mathrm{mPas}$ & $3400 \pm 0 \mathrm{mPas}$ & $9290 \pm 0 \mathrm{mPas}$ \\
\hline $30 \mathrm{rpm}$ & - & $96 \pm 0 \mathrm{mPas}$ & $592 \pm 0 \mathrm{mPas}$ & $2220 \pm 0 \mathrm{mPas}$ & $3944 \pm 0 \mathrm{mPas}$ \\
\hline $60 \mathrm{rpm}$ & - & $88 \pm 0 \mathrm{mPas}$ & $522 \pm 0 \mathrm{mPas}$ & $1734 \pm 0 \mathrm{mPas}$ & $1960 \pm 0 \mathrm{mPas}$ \\
\hline
\end{tabular}

The number of experiments, $n=3$, The data were given in mean \pm SD.

Table 5: Viscosity of $1 \% \mathrm{w} / \mathrm{v}$ sida acuta hydrogel solution at different temperatures

\begin{tabular}{ll}
\hline Temperature $\left({ }^{\circ} \mathbf{C}\right)$ & Viscosity (mPa. s) \\
\hline 28 (Room temperature) & $71.4 \pm 0.00$ \\
40 & $46.4 \pm 0.00$ \\
60 & $33.8 \pm 0.00$ \\
80 & $25.2 \pm 0.00$ \\
\hline
\end{tabular}

The number of experiments, $n=3$, The data was given in mean \pm SD

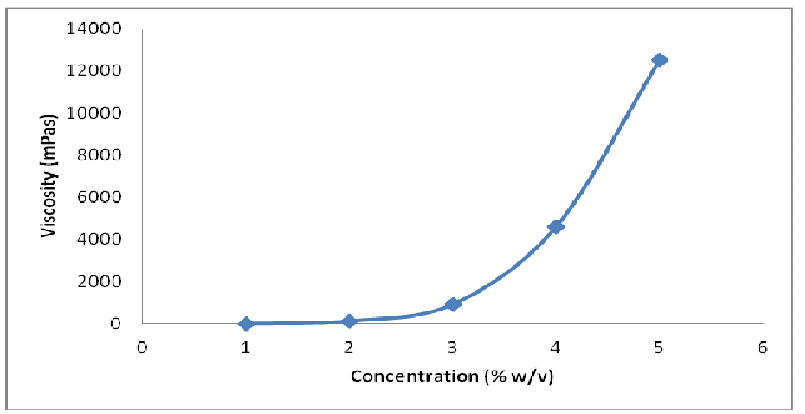

Fig. 2: Viscosity vs concentration at room temperature $\left(30^{\circ} \mathrm{C}\right)$ using rotor 3 at $6 \mathrm{rpm}$, The number of experiments, $n=3$, The data were given in mean $\pm S D$

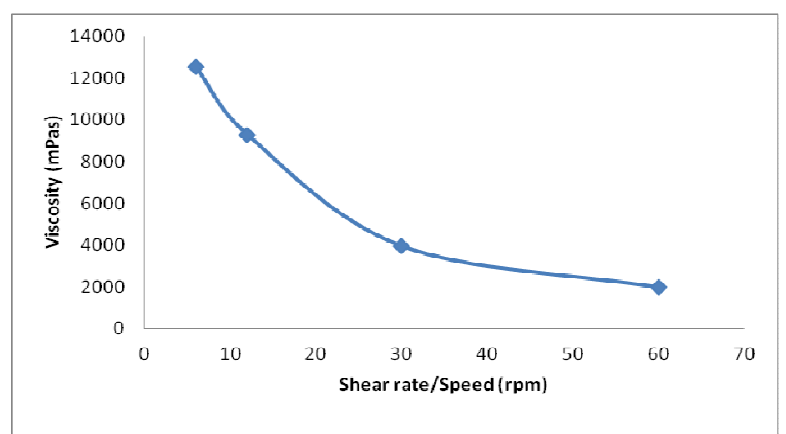

Fig. 3: Rheogram of $5 \% \mathrm{w} / \mathrm{v}$ sida acuta hydrogel solution at room temperature using rotor 3 , The number of experiments, $n$ $=3$, The data were given in mean \pm SD

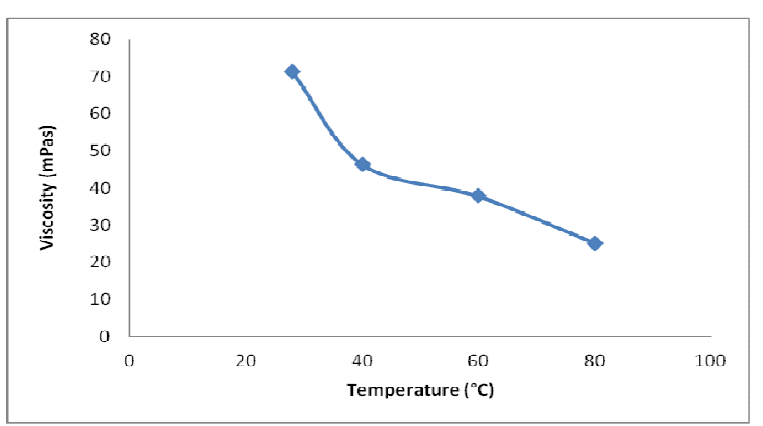

Fig. 4: Viscosity vs temperature using rotor 1 at $30 \mathrm{rpm}$, The number of experiments, $n=3$, The data were given in mean $\pm S D$

\section{Solubility}

The solubility of a substance is the amount of the substance that passes into solution in order to establish the equilibrium at constant temperature and pressure, to produce a saturated solution. Some factors such as temperature and $\mathrm{pH}$ affect the solubility of solids in liquids. [29] The mean solubility ( \pm SD) of $1 \% \mathrm{w} / \mathrm{v}$ Sida acuta hydrogel in distilled water at room temperature $\left(28 \pm 2{ }^{\circ} \mathrm{C}\right)$ and $80^{\circ} \mathrm{C}$ were found to be $7 \pm 0.41 \mathrm{mg} / \mathrm{ml}$ and $8.63 \pm 0.63 \mathrm{mg} / \mathrm{ml}$ respectively, while the solubility in $0.1 \mathrm{~N} \mathrm{HCl}$ and $0.1 \mathrm{~N} \mathrm{NaOH}$ solutions were $5.67 \pm 0.58$ $\mathrm{mg} / \mathrm{ml}$ and $11.86 \pm 1.75 \mathrm{mg} / \mathrm{ml}$ respectively. The official limit for solubility of acacia gum in distilled water at room temperature is 500 $\mathrm{mg} / \mathrm{ml}$ or Ig of acacia dissolves in $2 \mathrm{ml}$ of distilled water to form a slightly viscous solution. The results show that Sida acuta hydrogel is poorly soluble in distilled water at room temperature when compared to acacia gum. Also, the solubility increased as the temperature increased. The solubility decreased in $0.1 \mathrm{~N} \mathrm{HCl}$ but increased in $0.1 \mathrm{~N}$ $\mathrm{NaOH}$ solutions. This was in agreement with the $\mathrm{pH}$ value of the hydrogel $(6.60 \pm 0.09)$ which was slightly acidic. Basic substances are soluble in acidic solvents, vice versa. An increase in solubility of a new drug in an acidic solution compared with its aqueous solubility suggests a weak base, and an increase in alkali, a weak acid [30]. The fast swelling of the hydrogel in water may be one of the reasons for its poor solubility. Particles at the outer surface absorb water and swell which prevents water from reaching those in the interior easily. This feature may be useful if the hydrogel is used in the formulation of swellable hydrophilic matrix tablets.

\section{Ash values}

The total ash method is designed to measure the total amount of material remaining after ignition. This includes both "physiological ash", which is derived from the plant tissue itself, and "non-physiological" ash, which is the residue of the extraneous matter (e. g. sand and soil) adhering to the plant surface. Acid-insoluble ash measures the amount of silica present, especially as sand and siliceous earth. The mean total ash value $( \pm$ SD) for Sida acuta hydrogel was $53.33 \pm 5.77 \mathrm{mg}$ per $1 \mathrm{~g}$ hydrogel $(5.33 \% \mathrm{w} / \mathrm{w})$, while the mean acid insoluble ash $( \pm \mathrm{SD})$ and mean water soluble ash $( \pm \mathrm{SD})$ were $10 \pm 0.02 \mathrm{mg}$ per $1 \mathrm{~g}$ hydrogel $(1.0 \% \mathrm{w} / \mathrm{w})$ and $10 \pm 0.05 \mathrm{mg}$ per $1 \mathrm{~g}$ hydrogel $(1 . \% \mathrm{w} / \mathrm{w})$ respectively. The British Pharmacopeia limit of total ash and acid insoluble ash for acacia is not more than $4.0 \%$ and not more than $0.5 \%$ respectively [31]. The value obtained showed that there was a low level of impurity from extraneous and plant matters. The values obtained indicated that most of the impurities present as total ash were acid soluble i. e few sand and siliceous earth. The value obtained for water-soluble ash was also small $(1 \% \mathrm{w} / \mathrm{w})$. These values were comparable, though slightly higher than that obtained for acacia gum.

\section{Loss on drying}

British Pharmacopoeia's limit for percentage loss on drying for acacia gum is, not more than $15 \%$. The result obtained for mean 
percentage loss on drying $( \pm \mathrm{SD})$ was $14.5 \pm 1.87 \%$, and $14.5 \pm 1.32 \%$ for Sida acuta hydrogel and acacia gum respectively. The loss on drying obtained for the Sida acuta hydrogel was comparable to that of acacia. The value obtained for acacia was within the official limit. The result showed that Sida acuta hydrogel absorbed water easily without dissolving in it. This showed that the hydrogel could be used as a hydrophilic swellable matrix. The presence of such quantity of moisture showed that the hydrogel may be liable to microbial attack, therefore it should be properly stored in a dry closed container.

\section{Determination of browning and charring temperatures}

The hydrogel started browning at $265^{\circ} \mathrm{C}$ and charred at $268^{\circ} \mathrm{C}$.

\section{Microbial count}

There was no growth in the saboraund glucose agar plates containing the different dilutions of acacia gum and Sida acuta hydrogel solutions. This showed the absence of fungi in the acacia gum and Sida acuta hydrogel. The nutrient agar plates that contained $10^{-4}$ and $10^{-5}$ dilutions of Sida acuta hydrogel contained $132 \mathrm{cfu}\left(1.32 \times 10^{7} \mathrm{cfu} / \mathrm{ml}\right)$ and $79.5 \mathrm{cfu}\left(7.95 \mathrm{cfu} \times 10^{7} \mathrm{cfu} / \mathrm{ml}\right)$ of bacteria respectively. This was comparable to that obtained from the nutrient agar plates that contained 10-4 and 10-5 dilutions of acacia gum which contained $100 \mathrm{cfu}\left(1.00 \mathrm{X} 10^{7} / \mathrm{ml}\right)$ and $78.5 \mathrm{cfu}(7.85 \mathrm{X}$ $10^{7} \mathrm{cfu} / \mathrm{ml}$ ) of bacteria respectively. Therefore, when Sida acuta hydrogel is used in the formulation of liquid dosage forms as a suspending agent, preservatives should be added.

\section{Acute toxicity studies}

At the expiration of the $14 \mathrm{~d}$ as shown on table 5, there was no sign of toxicity or death recorded in the rats. From the study, the LD 50 value of Sida acuta hydrogel was above $2000 \mathrm{mg} / \mathrm{Kg}$, because neither obvious signs of toxicity nor death were observed.

Table 5: Acute toxicity studies of sida acuta hydrogel

\begin{tabular}{|c|c|c|c|c|}
\hline Group & Body mark & Body weight (g) & Dose (mg) & Number of death \\
\hline 1 & HR & 100 & 30 & 0 \\
\hline 1 & HRT & 90 & 27 & 0 \\
\hline 1 & HRR & 90 & 27 & 0 \\
\hline 1 & HT & 110 & 33 & 0 \\
\hline 1 & HTT & 100 & 30 & 0 \\
\hline 2 & $2 \mathrm{HH}$ & 100 & 200 & 0 \\
\hline 2 & 2IT & 80 & 160 & 0 \\
\hline 2 & 2II & 90 & 180 & 0 \\
\hline 2 & $2 \mathrm{TT}$ & 100 & 200 & 0 \\
\hline 2 & $2 \mathrm{HT}$ & 90 & 180 & 0 \\
\hline
\end{tabular}

Sample size: 10 rats

\section{CONCLUSION}

Sida acuta hydrogel was isolated from powdered dried leaves of Sida acuta. The hydrogel obtained had physicochemical properties that indicated that it could be used as pharmaceutical excipients such as a binder, suspending agent and swellable hydrophilic matrix. It could also be used for investigation in nanoformulation of some drugs in novel drug delivery alone or in combination with other biopolymers.

\section{ACKNOWLEDGEMENT}

The authors are grateful to the Department of Pharmaceutical Technology and Industrial Pharmacy, Faculty of Pharmaceutical Sciences, University of Nigeria, Nsukka, and the Department of Pharmaceutics and Industrial Pharmacy, Faculty of Pharmacy, Delta State University, Abraka, Nigeria, for making their laboratories available for this research work.

\section{CONFLICT OF INTERESTS}

\section{Declared none}

\section{REFERENCES}

1. Phani Kumar GK, Gangarao B, Kotha NS, Lova R. Isolation and evaluation of Tamarind seed polysaccharide being used as a polymer in pharmaceutical dosage forms. Res J Pharm Biol Chem Sci 2011;2:274.

2. Shweta M, Akanksha B, Nayyar P, Pramod KS. Extraction and use of Lallemantia royleana seed mucilage as a pharmaceutical excipient. World J Pharm Res 2015;4:1578-89.

3. Deshmukh SS, Katare YS, Shyale SS, Bhujbal SS, Kadam SD, Landge DA, et al. Isolation and evaluation of mucilage of Adansonia digitata Linn as a suspending agent. J Pharm 2013. http://dx.doi.org/10.1155/2013/379750

4. Kulkarni GT, Gowthamarajan K, Dhobe RR, Yohanan F, Suresh B. Development of controlled release spheroids using natural polysaccharide as a release modifier. Drug Delivery 2005;12:201-6.

5. Kokate CK, Purohi AP, Gokhale SB. Textbook of pharmacognosy. 18th ed. Pune: Nirali Prakashan; 2002.
6. Evans WC. Trease and Evans Pharmacognosy. New York: WB Saunders; 2004.

7. Pritam DC, Harshal AP. Recently investigated natural gums and mucilages as pharmaceutical excipients: an overview. J Pharm 2014. http://dx.doi.org/10.1155/2014/204849

8. Zatz JL, Kushla GP. Oral aqueous suspensions and gels. In: Reiger MM, Banker GS. editors. Pharmaceutical Dosage Forms: Disperse Systems. Vol. 2. New York: Marcel Dekker; 1989. p. 164-405.

9. Jani GK, Shah DP, Prajapatia VD, Jain VC. Gums and mucilages: versatile excipients for pharmaceutical formulations. Asian J Pharm Sci 2009;4:309-23.

10. Okafor IS, Chukwu A, Udeala OK. Some physicochemical properties of Grewia Gum. Nigerian J Polymer Sci Technol 2001;21:61-7.

11. Okafor IS, Chukwu A. The binding property of Grewia gum II: some physical properties of sodium salicylate tablets. West Afr J Biol Sci 2003;14:9-21.

12. Ogaji I. Characterization and application of grewia gum as a film coating agent in theophylline hydrochloride tablets. Pharm Pharm Technol; 2011. p. 308.

13. Nep EI, Okafor IS. Evaluation of the bioadhesive property of grewia gum in indomethacin tablet formulation in pig gastric mucous. J Pharm Bioresources 2006;3:62-9.

14. Udeala OK, Uwaga UN. Some emulsifying and suspending properties of a polysaccharide gum derived from Мисиna flagillepes, Papilionaceae. J Pharm Pharmacol 1981;33:75-8.

15. Udeala OK, Chukwu A. The binding property of mucuna gum in sulphadimidine and chloroquine phosphate tablets. Nigeria J Pharm Sci 1985;1:59-66.

16. Attama AA, Nwabunze OJ. Mucuna gum microspheres for oral delivery of glibenclamide: In vitro evaluation. Acta Pharm 2007;57:161-71.

17. Karou SD. Sida acuta Burm. f.: a medicinal plant with numerous potencies. Afr J Biotechnol 2007;6:2953-9.

18. Akilandeswari S. Antimicrobial activity of leaf extracts of Sida acuta burm. Int J Pharma Sci Res 2010;11:248-50.

19. Olabiyi TI, Oyedunmade EA, Ibikunle GJ, Ojo OA, Adesina GO, Adelasoye KA, et al. Chemical composition and bio-nematicidal 
potential of some weed extracts on Meloidogyne incognita under laboratory conditions. Plant Sci Res 2008;1:30-5.

20. Bouzouita N, Khaldi A, Zgoulli S, Chebil L, Chekki R, Chaabouni $\mathrm{MM}$, et al. The analysis of crude and purified locust bean gum: a comparison of samples from different carob tree populations in Tunisia. Food Chem 2007;101:1508-15.

21. Tabatabaee AB, Mirhosseini $H$. Influence of different purification and drying methods on rheological properties and viscoelastic behaviour of durian seed gum. Carbohydr Polym 2012;90:452-61.

22. Uzondu ALE, Okafo SE. Extraction and formulation of a herbal product: the crude flavonoid of Garcinia Kola Heckel (Bitter Kola) seeds into lozenges. Eur J Biomed Pharm Sci 2014;1:491-501.

23. British Pharmacopoeia. I and II. Determination of Swelling Index. London: The Pharmaceutical Press, Her Majesty's Stationery Office; 1993. p. A15.

24. Sameer NJ, Sachin MS, Sachin SS, Piyush KM. Formulation and evaluation of ciprofloxacin suspension using natural suspending agent. Int J Pharm Sci Res 2014;5:63-70.

25. Dakia PA, Blecker C, Robert C, Wathelet B, Paquot M. Composition and physicochemical properties of locust bean gum extracted from whole seeds by acid or water dehulling pre-treatment. Food Hydrocol 2008;22:807-18.

26. Tabatabaee AB, Mirhosseini H. Optimization of aqueous extraction of gum from Durian (Durio zibethinus) seed: a potential, low-cost source of hydrocolloid. Food Chem 2012;132:1258-68.

27. Quality control methods for medicinal plant materials. Geneva: World Health Organization; 1998. p. 8-45.

28. Organization for Economic Cooperation and Development. OECD guidelines for acute toxicity of chemicals. Environmental Health and Safety Monograph Series on Testing and Assessment; 2001. p. 420.

29. Richards JH. Solubility and dissolution rate. In: Aulton ME. editor. Pharmaceutics: the science of dosage form design. International student edition. Edinburgh: Churchill Livingstone; 1999. p. 62-80.

30. Wells JI, Aulton ME. Preformulation. In: Aulton ME. editor. Pharmaceutics: The science of dosage form design. International student edition. Edinburgh: Churchill Livingstone; 1999. p. 223-53.

31. British Pharmacopoeia. Vol. I and II. London: The Pharmaceutical Press: Her Majesty's Stationery Office; 2003. p. 39-40.

\section{How to cite this article}

- $\quad$ Okafo Sinodukoo Eziuzo, Chukwu Amarauche. studies on Sida acuta hydrogel i: processing and physicochemical properties of the derived hydrogel obtained from south east nigeria. Int J Pharm Pharm Sci 2017;9(6):5-11. 